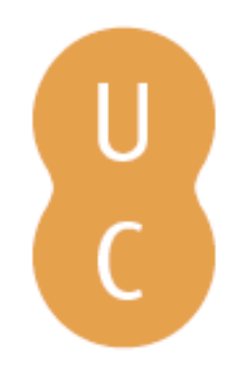

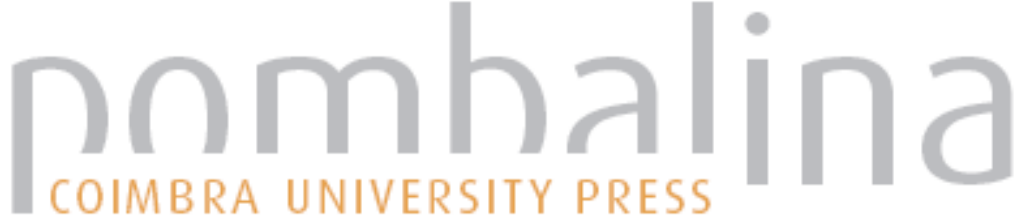

\section{Facilitators and barriers to active and healthy aging}

\author{
Autor(es): $\quad$ Martins, Anabela Correia
}

Publicado por: Imprensa da Universidade de Coimbra

URL

persistente: URI:http://hdl.handle.net/10316.2/32539

DOI: $\quad$ DOI:http://dx.doi.org/10.14195/978-989-26-0732-0_17

Accessed : $\quad$ 26-Apr-2023 10:41:17

A navegação consulta e descarregamento dos títulos inseridos nas Bibliotecas Digitais UC Digitalis, UC Pombalina e UC Impactum, pressupõem a aceitação plena e sem reservas dos Termos e Condições de Uso destas Bibliotecas Digitais, disponíveis em https://digitalis.uc.pt/pt-pt/termos.

Conforme exposto nos referidos Termos e Condições de Uso, o descarregamento de títulos de acesso restrito requer uma licença válida de autorização devendo o utilizador aceder ao(s) documento(s) a partir de um endereço de IP da instituição detentora da supramencionada licença.

Ao utilizador é apenas permitido o descarregamento para uso pessoal, pelo que o emprego do(s) título(s) descarregado(s) para outro fim, designadamente comercial, carece de autorização do respetivo autor ou editor da obra.

Na medida em que todas as obras da UC Digitalis se encontram protegidas pelo Código do Direito de Autor e Direitos Conexos e demais legislação aplicável, toda a cópia, parcial ou total, deste documento, nos casos em que é legalmente admitida, deverá conter ou fazer-se acompanhar por este aviso.

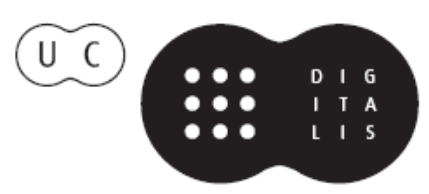


MPRENSA DA

UNIVERSIDADE

DE COIMBRA

COIMBRA

UNIVERSITY

- PRESS 


\title{
FACILITATORS AND BARRIERS TO ACTIVE \\ AND HEALTHY AGING
}

\author{
Anabela Correia Martins ${ }^{47}$
}

\begin{abstract}
The International Classification of Functioning, Disability and Health (ICF) was approved by the World Health Assembly in 2001. Ten years later, we have seen strong arguments on how the ICF can add value to the policies on active ageing and to investigating outcomes in healthy aging. As a conceptual framework, the ICF has universality because of its inclusive and comprehensive view of human functioning. At a practical level the ICF can be used to quantify the impact of impairment on an individual's ability to function in his/her environment and to assess interventions to minimize the impact of disability and maximize functioning. Health Promotion supports the notion that being healthy isn't just about 'not being sick' or physically unwell, it takes a bio-psycho-social view towards health, acknowledging that good health involves supportive environments, and social and emotional factors that affect health and well-being. Active aging is the process designed toward increasing and maintaining an individual's participation in activities to enhance his/her quality of life (WHO, 2001). The ICF gives a broad perspective and structured way to identify underlying facilitators and barriers to participation of THE elderly; there are several individual factors, like advanced lower extremity capacity, depressed mood, physically active lifestyle or cognitive function and environment factors, like assistive technologies, employment or rural living. Our aim is to address the advantages, opportunities and challenges, and limitations of ICF within the context of its use by active aging researchers and agents to generate discussion and contribute to developing potential solutions to promote active aging.
\end{abstract}

Keywords: Active aging; ICF; Barriers/facilitators.

47 Instituto Politécnico de Coimbra ESTESC-Coimbra Health School, Portugal

Email: anabelacmartins@estescoimbra.pt 


\section{Introduction}

"Healthy aging", "successful aging" and "active aging" are defined as the process of optimising opportunities for physical, social and mental health to enable older people to take an active part in society without discrimination and to enjoy an independent and good quality of life (European Commission, 2007).

The World Health Organization (WHO) (2002) assumed this as the process designed toward increasing and maintaining an individual's participation in activities to enhance his/her quality of life.

Participation is a person's involvement in a real-life situation and representing the societal perspective of functioning (WHO, 2001) and social participation in communities is one way to exercise a sense of competence and control (Zimmerman, 2000) and a sense of coherence, a mechanism which reduces reactivity to stress.

Variables determining the development, structure of social participation and functioning are multiple and need to be analysed at different levels.

\section{The role of contextual factors}

The International Classification of Functioning, Disability and Health (ICF) captures human functioning as the result of the interaction between body and environment, measured through activity and participation (WHO, 2001) (Figure 21).

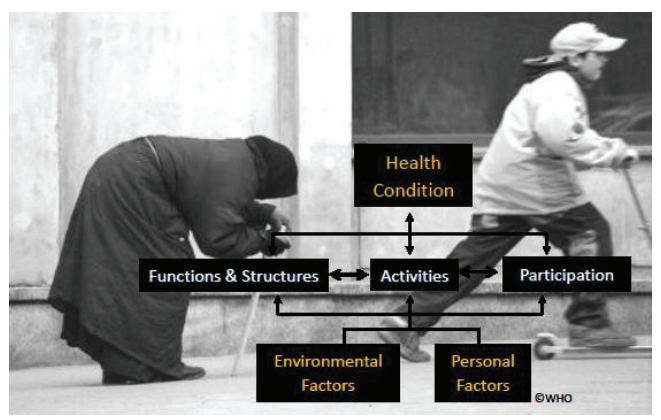

Figure 39: Multi-dimensions of human functioning 
Figure 39 demonstrates the role that contextual factors (i.e., environmental and personal factors) play in the process. These factors interact with the individual with a health condition and determine the level and extent of the individual's functioning. Environmental factors, a component of ICF, are extrinsic to the individual, such as the physical world and its features, the human-made physical world, other people in different relationships and roles, attitudes and values, social systems and services, and policies, rules and laws (e.g., the attitudes of the society, architectural characteristics, the legal system) and are classified in the environmental factors classification in five chapters: Chapter 1 Products and technology; Chapter 2 Natural environment and human-environment; Chapter 3 Support and relationships; Chapter 4 Attitudes, and Chapter 5 Services, systems and policies. Personal factors, on the other hand, are not classified in the current version of ICF. However, they are included in Figure 21 to show their contribution, which may have an impact on the outcome of various interventions. They are contextual factors that relate to the individual such as gender, race, age, other health conditions, fitness, lifestyle, habits, mood, coping styles, social background, education, profession, past and current experience (past life events and concurrent events), overall behavior pattern and character style, individual psychological assets and other characteristics, all or any of which may play a role in disability at any level (WHO, 2001).

The ICF gives a broad perspective and structured way to identify underlying facilitators and barriers to participation of human beings; facilitators are factors in a person's environment that, through their absence or presence, improve functioning and reduce disability (WHO, 2001).

According to the WHO classification, there are negative and positive scales for the extent to which an environmental factor acts as a barrier or a facilitator. A point or separator alone denotes a barrier, and the + sign denotes a facilitator, as indicated below:

xxx.0 NO barrier (none, absent, negligible,... ) 0-4\%

xxx.1 MILD barrier (slight, low,...) 5-24\%

Xxx.2 MODERATE barrier (medium, fair,...) 25-49\% 


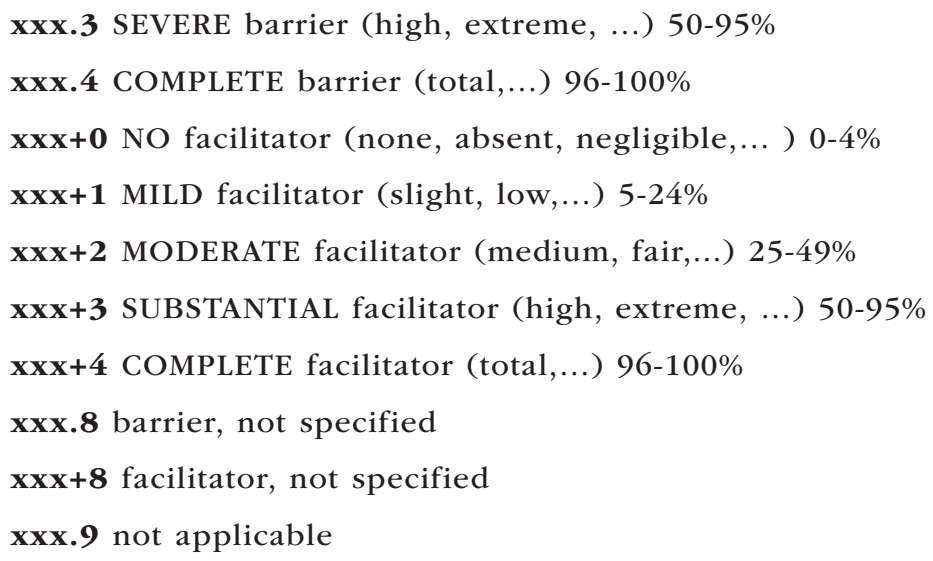

\section{Giving some examples of facilitators and barriers}

Environmental factors include aspects such as a physical environment that is accessible (e.g., design, construction and building products and technology for gaining access to facilities inside buildings for public use, such as washroom facilities, audio loops, lifts or elevators, and dispersed accessible seating in auditoriums or stadiums might be substantial facilitators: e1501+3); the availability of relevant assistive technology enhances capacity and performance (e.g., general products and technology for personal use in daily living, like a timer can substantially facilitate a domestic activity like cooking: e1150+3; assistive products and technology for personal use in daily living, like a voice-controlled systems might be a total facilitator, e $1151+4$, assisting people in daily living; assistive products and technology for personal indoor and outdoor mobility and transportation, like adaptations to vehicles, wheelchairs, scooters and transfer devices can moderately facilitate mobility: e 1201+2); positive attitudes of people towards disability (e.g., individual attitudes of immediate family members, particularly, general or specific opinions and beliefs of immediate family members about the person or about other matters, that influence individual behavior and actions, can be a strong facilitator: e $410+4)$, as well as services, systems and policies that aim to increase the involvement of all people with a health condition in all 
areas of life (e.g., open space planning services, systems and policies, like an adapted fitness area in a public park, can substantially facilitate physical activity: e520+3). Absence of a factor can also be facilitating, for example the absence of stigma or negative attitudes. Facilitators can prevent impairments or activity limitation from becoming a restriction on participation, since the actual performance of an action is enhanced, despite the person's problem with capacity.

Barriers are factors in a person's environment that, through their absence or presence, limit functioning and create disability (WHO, 2001). These include aspects such as a physical environment that is inaccessible (e.g., design, construction and building products and technology for gaining access to facilities inside buildings for public use, such as lifts or elevators might be complete barriers: e 1501.4); lack of relevant assistive technology (e.g., assistive products and technology for personal indoor and outdoor mobility and transportation, like a transfer device, might be a severe barrier: e 1201.3); negative attitudes of people towards disability (e.g., individual attitudes of acquaintances, peers, colleagues, neighbors and community members, can prevent someone from participating in social activities: e425.4), as well as services, systems and policies that are either non-existent (e.g., health services, systems and policies: e580.4) or that hinder substantially the involvement of all people with a health condition in all areas of life (e.g., transportation services: e5400.3).

\section{ICF and active aging}

As mentioned, the ICF framework is based on the concept that health and social functioning are influenced by complex interactions between contextual factors and body functions and structures (e.g., impaired balance, loss of strength or aerobic capacity), as well as activities and participation (e.g., washing oneself, dressing, eating, maintaining one's health, preparing meals, walking, moving around, assisting others, reading, voting, or attending public events). 
Several researches have been addressed the advantages, opportunities and challenges, and limitations of the ICF biopsychosocial approach to developing potential solutions to promote healthy aging (Bickenbach, 2003; Clarke \& Nieuwenhuijsen, 2009; Arnadottir, Gunnarsdottir, Stenlund \& Lundin-Olsson, 2011); recognizing the potential impact of personal and environmental factors should be the beginning.

A person who experienced a cerebral vascular accident can demonstrate impairments in body functions and structures, like lack of strength, increased tonus or postural and balance impairments that leads to difficulty in walking (activity limitation), which may restrict his or her involvement in life situations, such as meeting with close friends (participation restriction) or going to the park. However, he or she may continue to be active in social participation if he or she lives in an environment with an extensive and accessible public transit system or if he or she uses specific devices designed to facilitate moving around, such as a wheelchair or a scooter for moving to his or her friends' house or going to the village park.

In Portugal, assistive technology (AT) services were detected as ineffective concerning evaluation, recommendation, advocacy, training and outcome measuring of their clients. However, it is an opportunity to rethink AT services, policies and politics to sustain community-dwelling older adults. Chronic diseases and aging will be a world-scale problem in the future, and AT will play a key role in supporting people's independence and in helping society save economic and human resources preventing or delaying assisted living or nursing homes. AT concerns: 1) devices, that are used to increase, maintain, or improve a person's functional capabilities, and 2) services that help an individual select, acquire, or learn to use an AT device. These services include customizing, adapting, maintaining, and repairing devices, AT evaluations, funding, and technical assistance and training in device use.

Active aging agents should be aware of the newest high technology devices introduced on the market, payment sources and state AT programs as well as destigmatizing dependence associated to AT.

Other studies have related specifically the contextual factors with older adult participation. According to Clarke and Nieuwenhuijsen (2009) and 
Markham and Gilderbloom (1998) environmental barriers subjectively reported by older adults include poor transportation, discontinuous or uneven sidewalks, curbs, noise, and inadequate lighting.

Extreme climates have also been related to older adult health outcomes (Aylin, Morris, Wakefield, Grossinho, Jarup \& Elliot, 2001).

Several researches on pedestrian-oriented designs (e.g. continuous, barrier-free sidewalks, four-way stop signals, and pedestrian amenities) and access to recreational facilities have been shown to be positively associated with physical activity and self-rated health in older adults, and negatively related to obesity (Humpel, Owen \& Leslie, 2002; Addy et al., 2004; Patterson \& Chapman, 2004; Fisher, Li, Michael \& Cleveland, 2004; Berke, 2007; Michael et al., 2006; Li \& Fisher, 2004).

Poor street conditions, heavy traffic, and excessive noise have been shown to be associated with the onset of mobility limitations (Balfour \& Kaplan, 2002; Schootman et al., 2006).

Curb cuts (depressed curbs that act as ramps in sidewalks), smooth pavements, and barrier-free sidewalks are some of the environmental factors that can enhance independence and social participation in older adults at greatest risk, such as those who are socially isolated, prone to falling, or those with underlying weakness in movement-related functions and balance (Clarke \& Nieuwenhuijsen, 2009).

Persons who adjust well to unexpected events, like aging, generally lead healthy, active and happy lives, but those with negative acceptance have a harder time accepting their changes in appearance and have difficulty in coping. It is the moment to highlight the role of personal factors, like self-efficacy and attitudes.

Self-efficacy was defined as the person's confidence in being able to perform a behavior (Bandura, 1977) and subjective happiness is a goal to achieve (Lyubomirsky \& Lepper, 1999). It is suggested that self-efficacy and personal attitudes are key factors in improving social participation, an emergent outcome measure for active aging. Helping older persons to be successful in activities they consider meaningful, controlling their degree of difficulty/reducing the negative feedback, helping them to find their capacities, giving them time to find solutions, and promoting 
positive attitudes may promote greater social participation (Booth, Owen, Bauman, Clavisi \& Leslie, 2000; Reed, 2002; Rubin \& Roessler, 2001).

\section{Conclusion}

Social and health professionals and agencies should have knowledge and understanding of the multiple factors that influence active aging (addressed by ICF) and programs should provide appropriate resources, like assistive technologies, physical training, self-management in activities of daily living and social rules, problem-solving strategies, self-confidence in order to enhance quality of life and well-being. Besides, policies on healthy aging, professional bottom-up approaches, promoting empowerment and security, as well as family, friends and community in general can play an important emotional role, facilitating the role of older persons through inclusion in active life.

ICF has been preconized as a tool that professionals should use to encourage people-centered practice and increase their participation in decision-making for more effective and practical lower costs (WHO, 2001, 2002). Although ongoing work is needed to prove and support the utility of the ICF to identify facilitators and barriers to active and health aging, others have already proved the impact of, for example, assistive technologies or human support in fast variation in functioning and participation of elderly. Services, policies and politics or simply, the climate or light, should also be studied, as well as personal factors, which could represent an innovative research framework to address their impact in active and health aging, as suggested by the WHO (2001:251) in the "development of a Personal Factors component", which still does not exist.

\section{References}

Addy, C. L., Wilson, D. K., Kirtland, K. A., Ainsworth, B. E., Sharpe, P., \& Kimsey D. (2004). Associations of perceived social and physical environmental supports with physical activity and walking behavior. American Journal of Public Health, 94, 440-3. 
Andresen, E. M., Fouts, B. S., Romeis, J. C., \& Brownson, C. A. (1999). Performance of health-related quality-of-life instruments in a spinal cord injured population. Archives of Physical Medicine and Rehabilitation, 80(8), 877-884.

Arnadottir, S. A., Gunnarsdottir, E. D., Stenlund, H., \& Lundin-Olsson, L. (2001). Determinants of self-rated health in old age: A population-based, cross-sectional study using the International Classification of Functioning, BMC Public Health, 11, 670. Retrieved from http://www.biomedcentral.com/1471-2458/11/670.

Aylin, P., Morris, S., Wakefield, J., Grossinho, A., Jarup, L., \& Elliot, P. (2001). Temperature, housing deprivation and their relationship to excess winter mortality in Great Britain, 1986-1996. International Journal of Epidemiology, 30, 1100-8.

Balfour, J. L., \& Kaplan, G. A. (2002). Neighborhood environment and loss of physical function in older adults: evidence from the Alameda County Study. American Journal of Epidemiology, 155, 507-15.

Bandura, A. (1977). Self-efficacy: Toward a unifying theory of behavioural change. Psychological Review, 84, 191-215.

Berke, E. M., Koepsell, T. D., Moudon, A. V., Hoskins, R. E., \& Larson, E. B. (2007). Association of the built environment with physical activity and obesity in older persons. American Journal of Public Health, 97(3), 486-92.

Bickenbach, J. E. (2003). Functional status and health information in Canada: Proposals and prospects. Health Care Financing Review, 24, 89-102.

Booth, M. L., Owen, N., Bauman, A., Clavisi, O., \& Leslie, E. (2000). Social-cognitive and perceived environment influences associated with physical activity in older Australians. Preventive Medicine, 31(1), 15-22.

Clarke, P., \& Nieuwenhuijsen, E. R. (2009). Environments for healthy ageing: A critical review. Maturitas, 64, 14-19.

Elfstrom, M. L., Rydén, A., Kreuter, M., Taft, C., \& Sullivan, M. (2005). Relations between coping strategies and health-related quality of life in patients with spinal cord lesion. Journal of Rehabilitation Medicine, 37, 9-16.

European Commission. (2007). Healthy Ageing: A Challenge for Europe. Swedish National Institute for Public Health, Stockholm, Sweden.

Fisher, K. J., Li, F., Michael, Y., \& Cleveland, M. (2004). Neighborhood-level influences on physical activity among older adults: a multilevel analysis. Journal of Aging and Physical Activity, 11, 45-63.

Humpel, N., Owen, N., \& Leslie, E. (2002). Environmental factors associated with adults' participation in physical activity. American Journal of Preventive Medicine, 22, 188-99.

Li, F., \& Fisher, K. J. (2004). A multilevel path analysis of the relationship between physical activity and self-rated health in older adults. Journal of Physical Activity and Health, 1, 398-402.

Lyubomirsky, S., \& Lepper, H. S. (1999). A measure of subjective happiness: Preliminary reliability and construct validation. Social Indicators Research, 46, 137-155.

Markham, J. P., \& Gilderbloom, J. I. (1998). Housing quality among the elderly: A decade of changes. International Journal of Aging and Human Development, 46(1), 71-90.

Michael, Y., Beard, T., Choi, D., Farquhar, S., \& Carlson, N. (2006). Measuring the influence of built neighborhood environments on walking in older adults. Journal of Aging and Physical Activity, 14, 302-12. 
Patterson, P. K., \& Chapman, N. J. (2004). Urban form and older residents' service use, walking, driving, quality of life, and neighborhood satisfaction. American Journal of Health Promotion, 19, 45-52.

Reed, B. J. (2002). Assistive technology. In J. D. Andrew, \& C. W. Faubion (Eds.), Rehabilitation services: An introduction for the human services professional (pp. 198-237). Osage Beach, Mo: Aspen Professional Services.

Rubin, S. E., \& Roessler, R. T. (2001). Foundations of the vocational rehabilitation process. Austin, TX: Pro-Ed, Inc.

Schootman, M., Andresen, E. M., Wolinsky, F. D., Malmstron, T. K., Miller, J. P., \& Miller, D. K. (2006). Neighborhood conditions and risk of incident lower-body functional limitations among middle-aged African Americans. American Journal of Epidemiology, 163, 450-8.

World Health Organization. (2001). International Classification of Functioning, Disability and Health. Geneva: Classification, Assessment, Surveys and Terminology Team.

World Health Organization. (2002). Towards a Common Language for Functioning, Disability and Health. Geneva: World Health Organization.

Zimmerman, M. A. (2000). Empowerment Theory. Psychological, Organizational and Community Levels of Analyses. In J. Rappaport, \& E. Seidman, Handbook of Community Psychology (pp. 43-63). New York: Kluwer Academic/Plenum Publishers. 